Issue no. $27 / 2018$

\title{
INNOVATIVE ACTIVITIES OF FAMILY SMES: CASE STUDY OF THE SLOVAK REGIONS
}

Doc. PhDr. Ing. Ladislav Mura, PhD.

Pan-European University, Faculty of Economics and Business, Department of International Entrepreneurship, Bratislava, Slovakia. ladislav.mura@,gmail.com

JUDr. Ing. Michal Mazák

Pan-European University, Faculty of Economics and Business, Department of Economics, Bratislava, Slovakia. mazak@1xt.sk

\section{DOI:10.24193/OJMNE.2018.27.06}

\begin{abstract}
Building a competitive economy is based on the existence of competitive regions whose essential element in terms of sustainable development is the effectively functioning business sector. Typical representatives of the regional economy are the small and medium enterprises that often have the character of family businesses. The challenging competitive environment requires proactive responses to turbulent changes, and innovative activities have to be pursued in order to maintain activities and development on the market. Innovation is the driving force behind the development; it is a key issue to survive in a competitive business environment. Despite their quarter-century presence, family business in Slovakia are not addressed enough attention. This was the basic motif to review the current situation on the market. 330 business entities were involved in the first phase of our research. The aim if this article is to explore the innovative activity of small and medium enterprises having a character of family businesses in the regions of Slovakia, and also identify those important determinants that influence the innovation ability of the family businesses. The Chi-Square Test of Independence, the Pearson correlation coefficient and the mean value statistics were applied in the research. The findings of our case study aimed to reveal the trends linked to the innovation activity of family businesses.
\end{abstract}

Keywords: Innovation activity, small and medium enterprises, family businesses, sustainable and competitive regions. 
Issue no. $27 / 2018$

\section{Introduction}

Entrepreneurship as a driving force for the development of the economy deserves the attention of all concerned. Particular attention should be addressed to small and medium enterprises since they account for $98 \%$ to $99 \%$ of the business entities. They represent the backbone of the economies based on market principles. In spite of their considerable importance, less attention is addressed to the development of family enterprises. They might play an important role in the life of the regional economy. Theoretical definition of family enterprise is not easy at all. There are several definitions what type of business can or cannot be considered a family business. There is no standard definition in domestic or international context that would make it easier to define and compare family businesses from different perspectives. A common feature is the presence of family member either in management or ownership of the enterprise.

The development of small and medium enterprises is primarily driven by innovation. Innovation provides an opportunity to increase the economic performance of the business sector, increase the productivity of the economy and raise competitiveness. Innovation is a tool to outstrip the competitors and survive in the fierce competition. It is fostered by globalization, integration and internationalization that attract businesses into the centre of a competition. If they want to be successful, they have to innovate their services and products. Undoubtedly, the intense innovation activity is dominantly characteristic for the start-ups, resp. small enterprises, referred to as start-ups. They form the subcategory of micro businesses. They enter the market with an entrepreneurial idea that is perfectly feasible. Another group of innovative enterprises is formed by spin-off businesses. These are emerging from parent companies. The business practice shows, that there is a significant number of enterprises in both subcategories of businesses that have a family business character. Family businesses will have an increasingly stronger position in innovative activities since they tend to be flexible, adaptable in their operations and have effective management compared to medium or large enterprises. All of the mentioned and other aspects predetermine them to be innovative and successful on the market. They enter the market not only with an excellent idea, product or service with a high added value for the customer, but also with high quality service. They can also contribute to creation of workplaces in different regions, because they 
can absorb the qualified workforce. The synergy will cause the regional economy to spin; will contribute to workplace creation, GDP growth and care of the local environment.

These ideas reflect the interest of the authors in research of the innovative small and medium enterprises with a family business character. We talk about the field of economic activity, where the research results would be interesting not only for the companies involved in the research, but also for the representatives of the regional authorities, consultancy companies and other experts.

\section{Theoretical background}

The issue of small and medium enterprises is being addressed by the EU and also the central authorities of the individual states. Small and medium enterprises represent more than $98 \%$ of all businesses and account for $60 \%$ of the GDP. Their biggest advantage is that they conduct their business activity also in the regions larger enterprises have no interest in, because the regions lack the necessary infrastructure or the segment they operate in is less profitable for them. It is undisputable that the small and medium enterprises have a significant presence also in countries with different levels of regional development. Although the scientific literature pays no adequate attention on small and medium enterprises having a character of family business, there are economic sectors, where these types of businesses have a significant position. It is particularly characteristic in the agricultural sector (e.g. primary production, wine-growing, winemaking); the sectors of food industry (bakery industry etc.)

Innovation is a key factor for small and medium businesses to remain successful. According to Dobai Korcsmáros and Seres Huszárik (2015) or Svec and Madlenak (2017), innovative activity of businesses has a proven impact on the sustainable development. Vetráková et al. (2018) or Hitka (2018) can see the sustainability of the business activity in networking, high quality of human resources and innovation. These ideas are supported by Zaušková (2010) or Baculakova and Gress (2015), who perceives networking and involvement in business clusters as the basic features of innovative entrepreneurship. Mikušová (2016) can support the same opinion. She examined the relationship between innovation and sustainability. Hajduová et al. (2015) targeted to identify the opportunities, 
Issue no. 27/2018

negative and positive impacts and effectiveness of implementing innovations in small and medium enterprises in Slovakia. Innovation is undoubtedly a key to ensure the sustainability of the entrepreneurial activity. The introduction of new and innovative processes in the company will result in improved products and services. Benešová et al. (2018) add that innovative business activities are ensuring the economic growth. It is necessary to maintain the market position. The economic growth of the region and the country is ensured by the activity of effectively functioning enterprises. The relationship between innovation activity and economic growth was addressed by Ahn et al. (2018). The authors conducted a deeper analysis of relationships through analysis and modelling in several sectors and structures of the economy. They have emphasized the importance of knowledge transfer into the business activity in the form of innovation. The transfer of knowledge is reflected not only in corporate innovations, but has direct impact on the social and economic development of the region the company operates in (Orlova et al., 2018). According to the team of authors lead by Lavrinenka (2016), the cooperation in development between the regions and enterprises is extremely important in terms of implementing innovations. The activities realized might be inspiring for other regions with similar structure. Entrepreneurs of the future are born, who should face innovation activities as a strategic tool to further existence of successful entrepreneurship (Lazányi, 2014).

In the publications of Strážovská and Jančíková (2016), small and medium enterprises gain a particular importance. They are referred to as the backbone of the national economy. These categories of businesses also struggle with different barriers they have to overcome during the realization of their business activities. They had been analysed by Szabo and Herman (2014) with an emphasis on examining the transit countries. Macroeconomic approaches to the assessment of innovative entrepreneurship were applied by Bosáková et al. (2013), focusing their research on quantifying the utilization of innovations based on a screening model. It is indisputably necessary to research the opportunities and the impact innovation activity has on functioning of the business. Koráb and Koudelková (2016) focused their attention on specifying what determines the innovation in small and medium businesses in the Czech Republic. Duda, Gaisor and Alebaite conducted a research on the sample of companies in small and medium sector in Poland. They found that small and medium 
enterprises in Poland innovate the most. It is necessary to develop interest in estimation of innovation potential, advised Machová et al. (2015). They have published a comprehensive monograph devoted to the complex concept of innovation in small and medium enterprises. Innovative enterprises will train innovative leaders (Lesáková et al. 2017).

Implementing and maintaining innovation requires a systematic approach and creation of innovation systems (Fenyvesi, 2015). Koval'ová and Kulčár (2017) call the process of managing innovation activities as innovation management. In their terms, the decisionmaking and realization of innovation is strongly supported by the use of modern information and communication technologies. Stacho et al. (2016) recommend creating a new or modifying the existing organizational structure of business to support the innovation activity of the company. For innovation of commercial and marketing activities of the companies Reicher, Komáromi and Szeghegyi (2015) advice IT support in forms of specialized softwares, in order to manage the customer relationship effectively. Successful introduction of innovation into business practice would not be possible without enthusiastic and motivated managers (Moczydłowska, Widelska, 2014). Innovations deserve versatile support (Lorincová, Potkány, 2016). According to the authors, it is not only about the creation of the basic institutional, legal and economic conditions to implement innovations into the everyday reality.

There are also other, equally important determinants of innovative business activities, identified as soft factors, because they are related to human qualities. Lazányi (2017) emphasizes the importance of trust. Trust in partners is an essential phenomenon in family business, which should be built and developed by businesses having no family business character. Kozubíková, Čepel and Zlámalová (2018) emphasize the importance of the entrepreneur's personality and their ability to involve other employees in creating new company values, contribute to innovations of business processes and products. Similar opinion is shared by Jovanović et al. (2018) and Cseh Papp et al. (2018), who are convinced that the personality of the entrepreneur with intellectual skills (Korsakiene et al., 2017) can act as a driving force for innovative activities that can make the company successful on the market. 
Issue no. $27 / 2018$

\section{Material and Methods}

The research of innovative activities and innovative capability of businesses is one of the most up-to-date issues among the professionals and scientific experts. Different approaches regarding the issue are provided by the scientific literature and scientific databases. The following methodological approach and scientific methods were applied for processing the partial issue of the research. To provide theoretical background, secondary literary sources were used, mainly the scientific publications of the authors published in scientific databases and periodicals. Domestic and foreign literary sources were used to respect the regional and economic specificities of the regions of Slovakia. In addition to secondary sources, it was necessary to gain primary data from the regions of Slovakia. Therefore a field research was conducted in all 8 self-governing regions of Slovakia in relation to small and medium enterprises. A total of 500 enterprises were addressed from the small and medium business sector with a character of family business. About 330 enterprises showed willingness to participate in the survey. It represents $66 \%$ of the businesses addressed. This step enabled a direct contact on business entities and made us possible to study their innovative capabilities and activities. Our goal was not to obtain a statistically representative sample from all the self-governing regions of Slovakia, but we approached to uncover the tendencies in the field of innovative activities of the family businesses. That is why we consider this phase of the research a case study. The aim of this article is to explore the innovative activities of small and medium enterprises having the character of family business in different regions of Slovakia. We also want to identify those determinants that influence the innovative ability of the family business. A questionnaire survey was conducted in order to collect primary data. The data obtained became a subject of a detailed statistical analysis. The gained data was analysed with a help of a special statistical software SPSS, followed by evaluation of the data. As a scientific method a dependency testing was applied during the statistical analysis, based on the Chi-Square Test of Independence ( $\chi^{2}$ test). The formulated hypothesis $\mathrm{H}_{0}$ about the independence is rejected on the level of significance $\alpha$ if the value of test criterion exceeds $100,(1-\alpha) \%$ quantile $\chi^{2}$ division by degrees of freedom $v=$ $(\mathrm{r}-1)(\mathrm{c}-1)$. The mathematical formula is the following: $\mathrm{K} \geq \chi^{2}{ }_{1-\alpha} ;(\mathrm{r}-1)$ (c-1). The significance level $\alpha=0,05$ was chosen for the test. We monitored the variables to see if any 
Issue no. $27 / 2018$

correlation exists. For calculation we used a linear regression through the Pearson's correlation coefficient:

$$
r=\frac{\sum(x-\bar{x})(y-\bar{y})}{\sqrt{\sum(x-\bar{x})^{2} \sum(y-\bar{y})^{2}}}
$$

The correlation coefficient has values from the interval $<-1,1>$. If the value of the correlation coefficient is 0 , it means no relationship exists between the variables examined. If the correlation coefficient reaches the value 1, a direct dependence between the variables can be detected. It means if the value of one variable increases, it is followed also by the other variable. If the correlation coefficient equals with the value -1 , the increase in the value of one variable results in decrease in the value of the other one. To supplement our evaluation we also applied the statistics of median value (primer, median, modus and standard deviation).

The presented research as we indicate below is a part of the research project no. 19/2018 GAAA, while the current research is deepening and extending the results of the scientific research VEGA 1/0381/13. The current research is focusing on the small and medium enterprises. Together with the start-ups they are considered to be the engines for further development of the business sector.

\section{Results and Discussion}

Using the scientific method of correlation analysis and the mean value statistics, we assessed the data obtained in our field research. The obtained database included the answers of respondents for the questionnaire survey. The answers were provided by small and medium family businesses. The questionnaire survey was conducted in the first half of 2018 in Slovakia.

In the practical part of the submitted article we will focus on the primary research conducted in the first phase of the research project with a focus on examining the factors influencing the activity of small and medium family businesses. Totally 330 small and medium family businesses entered the questionnaire survey; the data obtained underwent statistical analysis. 
Issue no. $27 / 2018$

Following the exclusion of extremes via Boxplot, the sample involved 320 questionnaires to be evaluated.

As a first step we looked at the results in the field of identifying the determinants of the innovation activity. We used the results of the questionnaire survey. The results are presented in Table 1.

Table 1 Statistical assessment of the innovation activity determinants

\begin{tabular}{|l|c|c|c|}
\hline \multicolumn{1}{|c|}{ Determinant of innovation competitiveness } & Average & Modus & $\begin{array}{c}\text { Standard } \\
\text { deviation }\end{array}$ \\
\hline Research and product development & 3.67 & 4 & 1.050 \\
\hline Technology life-cycle & 3.44 & 3 & 1.180 \\
\hline Variability of technology & 3.67 & 4 & 0.960 \\
\hline Cost of technological equipment & 3.42 & 3 & 0.980 \\
\hline Utilization of production capacities & 3.44 & 3 & 1.068 \\
\hline Product quality & 3.67 & 4 & 1.050 \\
\hline Number of products & 3.19 & 2 & 0.920 \\
\hline Practical use of product packaging & 3.33 & 3 & 0.920 \\
\hline Customer service & 3.42 & 3 & 0.980 \\
\hline Marketing activity & & 3 & 0.930 \\
\hline
\end{tabular}

Source: primary research, own processing

The Likert scale was applied to examine the determinants. According to the calculated results the most important determinants of innovation activity in small and medium enterprises were the research and development of products, the quality of products and the variability of technology. These were followed by the life-cycle of technology, utilization of 
Issue no. $27 / 2018$

production capacities and the cost of technical equipment. The values of average indicate that all the factors were marked by the respondents - representatives of companies involved in the survey - important; even in one case the monitored values did not fall under 3. The values of standard deviation clearly confirm the closeness in opinion of the respondents resp. a relevant match since the calculated values are close to 1 .

In addition to one-dimensional statistics, we have also expanded our analysis with a superstructure analysis - the research of mutual relations. First we determined the existence of dependence then applied the correlation analysis based on the Pearson correlation analysis. After identifying dependence between the variables, we were concerned about the strength of this dependence i.e. the intensity of correlation. The Pearson correlation coefficient is an appropriate method to detect the intensity of correlation. Before the analysis of itself we excluded the potential extremes. This exclusion was accomplished by using Boxplot. From the original sample of 330 respondents (enterprises), it was necessary to exclude 10 responses from the surveyed enterprises. The correlation analysis was performed at $\mathrm{N}=320$. The results are shown in Table 2.

Table 2. Analysis of correlation between the determinants of innovation

\begin{tabular}{|l|l|l|l|l|}
\hline Variable X & Variable Y & $\begin{array}{l}\text { Pearson's } \\
\text { correlation } \\
\text { coefficient }\end{array}$ & Sign. & N \\
\hline research, development & customer relationship & 0.190 & 0.004 & 320 \\
\hline research, development & motivation system & 0.382 & 0.000 & 320 \\
\hline motivation system & customer relationship & 0.386 & 0.000 & 320 \\
\hline effective work team & motivation system & 0.277 & 0.000 & 320 \\
\hline effective work team & customer relationship & 0.348 & 0.000 & 320 \\
\hline effective work team & research, development & 0.320 & 0.000 & 320 \\
\hline
\end{tabular}


Issue no. $27 / 2018$

\begin{tabular}{|l|l|l|l|l|}
\hline customer demand & research, development & 0.254 & 0.001 & 320 \\
\hline $\begin{array}{l}\text { organizational structure } \\
\text { of the company }\end{array}$ & $\begin{array}{l}\text { support of company } \\
\text { management }\end{array}$ & 0.262 & 0.000 & 320 \\
\hline $\begin{array}{l}\text { organizational structure } \\
\text { of the company }\end{array}$ & $\begin{array}{l}\text { cooperation with } \\
\text { business partners }\end{array}$ & 0.208 & 0.004 & 320 \\
\hline $\begin{array}{l}\text { own innovation potential } \\
\text { legislation, taxes, fees }\end{array}$ & 0.205 & 0.001 & 320 \\
\hline $\begin{array}{l}\text { own innovation potential } \\
\text { business partners }\end{array}$ & -0.190 & 0.008 & 320 \\
\hline $\begin{array}{l}\text { support of company } \\
\text { management }\end{array}$ & effective work team & 0.256 & 0.001 & 320 \\
\hline $\begin{array}{l}\text { support of company } \\
\text { management }\end{array}$ & research, development & 0.248 & 0.001 & 320 \\
\hline
\end{tabular}

Source: primary research, own processing

When evaluating the achieved statistical results, we can summarize the following facts: the value of Pearson's coefficient with the exception of 2 items ranges from 0.2 to 04 . It indicates the mean rate of positivity between the variables examined. The value of Pearson $r$ confirmed a relationship between the variables in several cases. This is especially true in the following cases: research, development and motivation system, motivation system and relation with customers, effective work team and the relation with customers or effective work team and research, development. These facts confirm the long-term results of the research on factors supporting innovation activity of the business entities.

We have also approached to confirmation of hypotheses we set. We were interested in verifying the validity of these hypotheses.

Hypothesis 1

$\mathrm{H}_{0}$ : There is no dependence between the motivation system of employees and the implementation of innovations in the company 
Issue no. $27 / 2018$

$\mathrm{H}_{1}$ : There is dependence between the motivation system of employees and the implementation of innovations in the company

Based on the results of the Chi-Squared Test $(p=0,008)$ at the significance level $\alpha=0,05$ we can reject the hypothesis $\mathrm{H}_{0}$. It means dependence between the motivation system of employees and the implementation of innovations in family businesses. In business practice this means that the effectively functioning motivation system encourages employees for innovation, thereby introducing innovative products and services to customers.

\section{Hypothesis 2}

$\mathrm{H}_{0}$ : We assume that there is no difference in the perception of the various factors that are the reasons for the company's innovation activity.

$\mathrm{H}_{1}$ : We assume that there is a difference in the perception of the various factors that are the reasons for the company's innovation activity.

Based on the results of the Chi-Square Test $(p=0,2802)$ we do not reject the Hypothesis $\mathrm{H}_{\mathrm{o}}$ at the level of significance $\alpha=0,05$, according to which there is no difference in the perception of different factors that justify the innovative activity of family enterprises. The businesses do not differentiate the individual factors that contribute to innovation activity. The companies involved in the sample are motivated by the same factors resulting in innovative activity.

To maintain the innovative competitiveness of enterprises involved in the survey, it is necessary to strengthen those determinants that positively correlate with the desired business results and have positive impact on the business activity. Those determinants that hinder the business development should be eliminated by the management. Only those determinants can be eliminated that are in the competence of the management, because the macroeconomic determinants resp. conditions determined by legislation cannot be directly influenced. The companies can only adapt to them. It will be necessary for the enterprises to improve and adapt to market changes. Only an entrepreneur who can flexibly and efficiently adapt his/her activities to the market environment can succeed on the globalized market. 
Issue no. $27 / 2018$

\section{Conclusion}

Family businesses are an essential part of the small and medium business sector, however in Slovakia they are not addressed enough attention. They have numerous advantages compared to small and medium or large enterprises not in family ownership. If these opportunities are exploited by the businesses, they can succeed in the fierce competition. One of the prerequisites for their entrepreneurial success is the innovative ability and the realization of innovative activities. New ideas, improvements and filling gaps on the market will result in success for these types of businesses. In the current scientific paper we have focused our attention on the review of the current situation in the field of innovation realized by family businesses as a segment of the small and medium enterprise sector. The results of the first phase of our research regarding the sample can be considered a case study that reveals the current trends in the surveyed area. Based on the results of the survey in 8 self-governing regions of Slovakia the following facts can be summarized:

$\checkmark$ Innovation is a prerequisite for survival in a fiercely competitive business environment. Without innovation and innovative activities the business is unable to survive. Innovation is important to maintain competitiveness.

$\checkmark$ Innovation activity of enterprises conducting their business activities in different regions contribute to increased competitiveness not only for the enterprise itself but also for the wider environment their business activity is realized in,

$\checkmark$ In the regions where business entities are involved in business networks are proved to be more successful on the market and achieve higher level of competitive advantage,

$\checkmark$ Key determinants of innovation have emerged as a result of the research. In order to support the development of conditions for the implementation of innovative activities, regional institutions, advisory organizations and the state itself (in charge of the implementation of the economic policy) should be responsible,

$\checkmark$ The development of business is influenced by the factors as quality, technical development, organization of work, marketing and sales. It was confirmed that the owners of family enterprises care more about the quality and innovation of their products and services. They face not only the business risk but the risk of personal reputation as well. This is a very powerful motivating factor. 
Issue no. $27 / 2018$

$\checkmark$ According to in-depth statistical analysis, the innovation activity of family businesses depends on the efficiently working team, motivation system, customer relationship resp. relationship with business partners and the support of the management team.

\section{Acknowledgement}

The scientific article represents a partial output of the research project no. 19/2018 GAAA aimed at examining the impact of internationalization on the business activity of small and medium family enterprises.

\section{References}

- AHN, S., YOON, J., KIM, Y. 2018. The innovation activities of small and mediumsized enterprises and their growth: quantile regression analysis and structural equation modeling. Journal of Technology Transfer, Vol. 43. Issue 2, pp. 316-342

- BACULAKOVA, K., GRESS, M. 2015. Cluster analysis of creative industries in the EU. Economic Annals-XXI, Vol. 9-10, pp. 15-18

- BENEŠOVÁ, D., KUBIČKOVÁ, V., MICHÁlKOVÁ, A., KROŠLÁKOVÁ, M. 2018. Innovation activities of gazelles in business services as a factor of sustainable growth in the Slovak Republic. Entrepreneurship and Sustainability Issues, Vol. 5, Issue 3, pp. 452466

- BOSÁKOVÁ, L., KUBÁK, M., ANDREJKOVIČ, M., HAJDUOVÁ, Z. 2013. Doing business abroad: utility function model for country selection in preliminary screening phase. Central European Journal of Operations Research, Vol. 23, Issue 1, pp. 53-68

- CSEH PAPP, I., VARGA, E., SCHWARCZOVÁ L., HAJÓS, L. (2018). Public work in an international and Hungarian context. Central European Journal of Labour Law and Personnel Management, Vol. 1., No. 1., pp. 6 - 15

- DOBAI KORCSMÁROS, E., SERES HUSZÁRIK, E. 2015. Innovation activity of corporations. Acta Oeconomica Universitatis Selye, Vol. 4, Issue 2, pp. 75-83

- DUDA, J., GASIOR, A., ALEBAITE, I. 2017. Innovation of Polish micro and small enterprises and trade credit. Transformations in Business and Economics, Vol. 16, Issue 3, pp. 89-108 
Issue no. $27 / 2018$

- FENYVESI, E. 2015. Systems of innovations and possibility of their joint. Acta Oeconomica Universitatis Selye, Vol. 4, Issue 2, pp. 53-63

- HAJDUOVÁ, Z., LACKO, R., MILDEOVÁ, S., STRIČÍK, M. 2015. Case study in the field of innovation in selected companies in Slovak Republic. Analele Stiintifice ale Universitatii Al I Cuza din Iasi - Sectiunea Stiinte Economice. Vol. 62, Issue 1, pp. 103119

- HITKA, M., JOŠČÁK, P., LANGOVÁ, N., KRIŠTÁK, L., BLAŠKOVÁ, S. 2018. Loadcarrying Capacity and the Size of Chair Joints Determined for Users with a Higher Body Weight. Bioresources, Vol. 13, Issue 3, pp. 6428-6443

- JOVANOVIĆ, I., ARSIĆ, M., NIKOLIĆ, D. 2018. Entrepreneurial personality traits and SMEs profitability in transition economy. Serbian Journal of Management, Vol. 13, Issue 1, pp. 89-104

- KORAB, V., KOUDELKOVA, P. 2016. What determines innovation in small and medium enteprises? A case study from the Czech Republic. Transformations in Business and Economics, Vol. 15, Issue 2, pp. 78-88

- KORSAKIENĖ, R., LIUČVAITIENĖ, A., BUŽAVAITĖ, M., ŠIMELYTÉ, A. 2017. Intellectual capital as a driving force of internationalization: a case of Lithuanian SMEs. Entrepreneurship and Sustainability Issues, Vol. 4, Issue 4, pp. 502-515

- KOVALOVÁ, M., KULČÁR, L. 2017. Innovation management and information acquisition. Acta Oeconomica Universitatis Selye, Vol. 6, Issue 2, pp. 101-108

- KOZUBÍKOVÁ, L., ČEPEL, M., ZLÁMALOVÁ, M. 2018. Attitude toward innovativeness based on personality traits in the SME sector. Czech Republic case study. Management and Marketing, Vol. 13, Issue 2, pp. 913-928

- LAVRinenKO, O., OHOTINA, A., TUMAlaViČIUS, V., PIDLISNA, O. V. 2016. Assessment of partnership development in cross-border regions' innovation systems (Latvia-Lithuania-Belarus). Journal of Security and Sustainability Issues Vol. 6, Issue 1, pp. $155-166$.

- LAZÁNYI, K. 2014. Entrepreneurs of the future. Serbian Journal of Management, Vol. 9, Issue 2, pp. 149-158 
- LAZÁNYI, K. 2017. Innovation - The role of trust. Serbian Journal of Management, Vol. 12 , Issue 2,12143

- LESÁKOVÁ, L., GUNDOVÁ, P., KRÁL, P., ONDRUŠOVÁ, A. 2017. Innovation Leaders, Modest Innovators and Non-innovative SMEs in Slovakia: Key Factors and Barriers of Innovation Activity. Organizacija, Vol. 50, Issue 4, pp. 325-338

- LORINCOVÁ, S., POTKÁNY, M. 2016. The proposal of innovation support in small and medium-sized enterprises. Production Management and Engineering Sciences Scientific Publication of the International Conference on Engineering Science and Production Management, ESPM 2015, pp. 157-162

- MACHOVÁ, R., MURA, L., KORCSMÁROS, E., SERES HUSZÁRIK, E., BULECA, J., HAVIERNÍKOVÁ, K. 2015. Inovačné podnikanie a hodnotenie inovačného potenciálu podnikatel'ských sietí. Brno: Tribun EU, 219 s. ISBN 978-263-0598-9

- MIKUŠOVÁ, M. 2016. Business and sustainable development. Research outcomes. Scientific Papers of the University of Pardubice, Series D: Faculty of Economics and Administration, Vol. 23, Issue 38, pp. 94-106

- MOCZYDŁOWSKA, J., WIDELSKA, U. 2014. Motivating managers - expectations and reality (Polish experience). Acta Oeconomica Universitatis Selye, Vol. 3, Issue 2, pp. 5363

- ORlOVA, L., GAGARINSKAYA, G., GORBUNOVA, Y., KALMYKOVA, O. 2018. Start-ups in the field of social and economic development of the region: a cognitive model. Entrepreneurship and Sustainability Issues, Vol. 5, Issue 4, pp. 795-811.

- REICHER, R., KOMÁROMI, N., SZEGHEGYI, Á. 2015. The possible success factors of introduction of CRM system at hungarian SMEs. Acta Polytechnica Hungarica, Vol. 12, Issue 8, pp. 215-229

- STACHO, Z., POTKÁNY, M., STACHOVÁ, K., MARCINEKOVÁ, K. 2016. The organizational culture as a support of innovation processes' management: A case study. International Journal for Quality Research, Vol. 10, Issue 4, pp. 769-784

- STRAZOVSKA, L., JANCIKOVA, E. 2016. Importance of family business for EU economies. Actual Problems of Economics, Vol. 182, Issue 8, pp. 33-40 
- SVEC, M., MADLENAK, A. 2017. Legal frameworks for the phygital concept. European Journal of Science and Theology, 13(6), pp. 209-217

- SZABO, Z. K., HERMAN, E. 2014. Productive entrepreneurship in the EU and its barriers in transition economies: A cluster analysis. Acta Polytechnica Hungarica, Vol. 11 , Issue 6, pp. 73-94

- VETRÁKOVÁ, M., HITKA, M., POTKÁNY, M., LORINCOVÁ, S., SMEREK, L. 2018. Corporate sustainability in the process of employee recruitment through social networks in conditions of Slovak small and medium enterprises. Sustainability (Switzerland), Vol. 10, Issue 5, 1670

- ZAUŠKOVÁ, A. 2010. Clusters-a tool for enhancing innovation performance and the competitiveness of regions. Communication Today, Vol. 1, Issue 1, pp. 43-64

\section{Contact}

doc. PhDr. Ing. Ladislav Mura, PhD., Pan-European University, Faculty of Economics and Business, Department of International Entrepreneurship, Tematínska 10, 85101 Bratislava, Slovakia. e-mail: 1adislav.mura@gmail.com - corresponding author JUDr. Ing. Michal Mazák, Pan-European University, Faculty of Economics and Business, Department of Economics, Tematínska 10, 85101 Bratislava, Slovakia.

e-mail: mazak@1xt.sk 